\title{
POLA KONSUMSI MAHASISWA PULANG KAMPUNG DAN MASYARAKAT PADA PANDEMI COVID-19 DI KOTA BANDUNG
}

\author{
Retno Anisa Larasati \\ STAI Yamisa Soreang Kabupaten Bandung \\ Email: retnoanisa@stai-yamisa.ac.id
}

\begin{abstract}
ABSTRAK
Penelitian ini bertujuan untuk mengetahui seberapa besar porsi anggaran yang digunakan dalam pembelian barang tertentu pada mahasiswa pulang kampung dan masyarakat di daerah Taman Sari Bawah Kota Bandung selama pandemi covid-19. Untuk itu penelitian ini menggunakan metode penelitian kualitatif melalui survei kepada mahasiswa dan masyarakat serta pengamatan secara online. Data yang diolah terutama diperoleh dari survey (data primer) dan dilengkapi dengan data sekunder (Pemkot Bandung/Kelurahan) secara online. Hasil penelitian menunjukan bahwa pola konsumsi mahasiswa pulang kampung pada pandemi covid-19 menghabiskan porsi anggaran untuk makanan, fashion, hiburan dan transportasi yang terdiri dari $(20 \%$, $10 \%$, 5\% dan 5\%) sedangkan pola konsumsi masyarakan pada pandemi covid-19 menghabiskan porsi anggaran untuk makanan; (ii) pendidikan; (iii) komunikasi; (iv) transportasi; (v) kesehatan (masing-masing berkisar 20\%, 35\%, 15\%, 5\% dan 35\%).
\end{abstract}

Kata Kunci : Pola konsumsi mahasiswa dan Pola konsumsi mahasiswa

\begin{abstract}
This study discusses the large budget used in the purchase of special items for students returning home and the community in Taman Sari Bawah Bandung during the co-19 pandemic. For this reason, this research uses qualitative research methods through surveys for students and the public as well as online research. The processed data is mostly obtained from surveys (primary data) and supplemented with secondary data (Bandung City / Kelurahan Government) online. The results showed the consumption patterns of students returning home in the co-19 pandemic spending the budget for food, fashion, budget and transportation consisting of $(20 \%, 10 \%, 5 \%$ and $5 \%)$ while the consumption patterns of the community in the co-19 pandemic spent a portion budget for food; (ii) education; (iii) communication; (iv) transportation; (v) health (holding $20 \%, 35 \%, 15 \%, 5 \%$ and $35 \%$, respectively).
\end{abstract}

Keywords: Student consumption patterns and community consumption patterns 


\section{PENDAHULUAN}

Semakin hari covid-19 sudah semakin luas menyebar di Indonesia termasuk di Kota Bandung. Menurut data di situs pantau Pemkot Bandung (2020), covid19.bandung.go.id, menjelaskan bahwa ada sekitar 68 kasus positif. Sebanyak 8 di antaranya sembuh, 20 meninggal dunia dan 40 masih dirawat. Kasus covid-19 ini juga berdampak ke segala bidang diantaranya bidang pendidikan, ekonomi, sosial, budaya, dll.

Seperti yang dijelas oleh Aknolt Kristian Pakpahanan (2020 : 1) menjelaskan bahwa pandemi COVID-19 memberikan implikasi ekonomi, sosial, dan politik tidak saja negara-negara besar akan tetapi hamper seluruh negara di dunia. Indonesia adalah salah satu negara yang terdampak terutama pada sisi ekonomi. Hal ini sejalan dengan Bernatal Saragih (2020 : 2), menjelaskan bahwa dampak dari penyebaran virus corona (covid-19) ini tentu akan mempengaruhi kehidupan masyarakat, baik secara ekonomi, sosial, dan pangan.

Kasus yang berkaitan dengan bidang pendidikan adalah diterapkannya kebijakan belajar dari rumah, sehingga mengakibatkan mahasiswa di beberapa daerah yang kuliah di Kota Bandung memutuskan untuk pulang ke daerahnya masing-masing. Kota Bandung merupakan salah satu kota pendidikan di Indonesia yang menurut sejarahnya sudah dimulai sejak 1866. Kini di kota Bandung terdapat 1023 SD atau MI Negeri dan Swasta, 250 SMP atau MTS Negeri dan Swasta, 184 SMA Negeri dan Swasta, 25 MA Negeri dan Swasta, 96 SMK Negeri dan Swasta, 8 PTN dan 143 PTS. Dengan adanya PTN dan PTS diperkirakan jumlah mahasiswa pada tahun 2013 sebanyak 16.127 jiwa sehingga menambah jumlah penduduk di kota Bandung.

Kasus yang berkaitan dengan bidang ekonomi contohnya pola konsumsi. Mahasiswa yang datang ke kota Bandung kebanyakan berasal dari luar kota, setiap mahasiswa membutuhkan kebutuhan. Kebutuhan yang sangat dibutuhkan mahasiswa salah satunya kebutuhan primer dan fasilitas. Pengeluaran konsumsi mahasiswa yang pulang kampung sebelum dan sesudah pandemi covid-19 ini menjadi perhatian peneliti.

Menurut Baginda Persaulian (2013 : 2) menjelaskan bahwa di Indonesia, konsumsi juga memiliki peran yang sangat dominan dalam perekonomian dimana kontribusi konsumsi terhadap perekonomian Indonesia sangat besar dan dominan yaitu antara 57,7\% sampai dengan 73,9\% dari Produk Domestik Bruto (PDB). Fluktuasi besaran konsumsi terjadi selama kurun waktu 1999-2008. Pada tahun 2001 kontribusi konsumsi mengalami penurunan cukup signifikan yaitu sebesar 16,2\% dari PDB, tetapi pada tahun berikutnya terus mengalami kecenderungan peningkatan seiring dengan peningkatan jumlah penduduk Indonesia dimana kebutuhan masyarakat atas barang dan jasa juga menunjukkan peningkatan.

Salah satunya di Kota Bandung, salah kota terbesar di Indonesia ini terdapat banyak tempat yang menyediakan kebutuhan primer dan fasilitas untuk mahasiswa bahkan masyarakat setempat yang berada dekat pondokan membuka lapangan usaha agar mempermudah mahasiswa memenuhi kebutuhannya. Mahasiswa sama halnya dengan masyarakat, melakukan aktivitas ekonomi sehari-hari termasuk konsumsi untuk kepentingan dirinya sendiri, dimana didalamnya mengatur pola konsumsi sehari-hari. 
Konsumsi merupakan suatu kegiatan masyarakat yang dapat dipengaruhi oleh faktor pendapatan, lingkungan dan kebutuhan. Pola konsumsi masyarakat atau individu termasuk mahasiswa berbeda-beda. Pola konsumsi mahasiswa di setiap fakultas berbeda menurut kebutuhannya masing-masing seperti keperluan kuliah diantaranya pembelian buku-buku dan alat-alat praktek yang besar biayanya tidak sama. Contohnya mahasiswa yang kuliah di fakultas tekhnik akan lebih banyak mengeluarkan biaya untuk pembelian alat-alat praktek, seperti meja gambar dan pena gambar, dibandingkan dengan mahasiswa yang kuliah di fakultas ekonomi, dimana pada fakultas ekonomi tidak banyak memakai alat-alat praktek. Contoh lain adalah mahasiswa fakultas kedokteran yang mengeluarkan biaya lebih besar untuk membeli buku dan membeli alat-alat praktek dibandingkan dengan mahasiswa yang kuliah di fakultas pertanian dan fakultas-fakultas lainnya. Selain kebutuhan untuk biaya perkuliahan juga fasilitas tempat tinggal bagi mahasiswa yang berasal dari luar daerah, mereka harus mencari tempat tinggal seperti pondokan mahasiswa.

Hal ini sejalan dengan E. Indrinawati (2017 : 5), yang menjelaskan bahwa tingkat konsumsi mahasiswa dipengaruhi oleh tingkat pendapatan dan pengetahuan ekonomi yang mereka miliki, sehingga pengeluaran mahasiswa fakultas ekonomi akan berbeda dengan mahasiswa fakultas kedokteran

Kehadiran mahasiswa di Taman Sari Bawah mengakibatkan kehidupan masyarakat berubah, karena adanya interaksi yang dilakukan dengan mahasiswa. Interaksi biasanya terjadi dengan pemilik pondokan, warung makan, pemilik usaha laundry, jasa photo copy, warung kelontong dan masyarakat penyedia fasilitas mahasiswa lainny, sehingga dari interaksi tersebut dapat mengubah perilaku konsumtif masyarakat.

Hal ini sejalan dengan Mufidah (2012 : 2), yang menjelaskan bahwa saat ini, kegiatan konsumtif yang dilakukan oleh masyarakat perkotaan yang tinggal di pinggir kota tidak hanya didorong oleh adanya kebutuhan akan fungsi barang tersebut semata. Akan tetapi, juga didasari oleh keinginan yang sifatnya untuk menjaga gengsi. Hal itu karena semakin banyaknya penawaran dari produk terbaru yang promosinya dilakukan melalui media cetak maupun elektronik bahkan melalui penjualan langsung di tempat yang membuat seseorang menjadi mudah terpengaruh untuk mencoba.

Masyarakat atau penduduk asli di daerah Taman Sari Bawah diduga masih menggambarkan masyarakat pinggir kota (Sub Urban Society) dengan karakteristik berpendapatan menengah-bawah, tingkat pendidikan rata-rata SMU dan menganut nilainilai budaya penduduk asli. Masyakarat pinggir kota memiliki kecenderungan meniru seperti yang digambarkan oleh Duesenberry melalui relative income hypothesis nya. Duesenberry (1949) menjelaskan adanya "demonstration effect" yang dalam konteks penelitian ini adalah efek demonstrasi dari mahasiswa kepada masyarakat pinggir kota tersebut. James Duesenberry mengemukakan tentang teori konsumsi dengan hipotesis pendapatan relatif menggunakan dua asumsi, yaitu :

1. Selera rumah tangga atas barang konsumsi adalah interdependen. Artinya pengeluaran konsumsi rumah tangga dipengaruhi oleh pengeluaran yang dilakukan oleh orang sekitarnya (tetangganya). 
2. Pengeluaran konsumsi adalah irreversible. Artinya, pola pengeluaran seseorang pada saat penghasilan naik berbeda dengan pola pengeluaran pada saat penghasilan mengalami penurunan.

Asumsi yang pertama dalam teori Duesenberry (1949) menyatakan bahwa konsumsi seseorang atau kelompok masyarakat dalam waktu tertentu merupakan fungsi dari konsumsi orang lain atau kelompok lainnya atau yang lebih dikenal efek demonstrasi.

Efek demonstrasi merupakan efek pada perilaku individu yang disebabkan oleh pengamatan tindakan orang lain (dalam penelitian ini diasumsikan didapatkan dari interaksi antar keduanya). Efek demonstrasi yang terjadi mengakibatkan sebagian pola konsumsi masyarakat mengikuti mahasiswa. Namun, asumsi ini dapat berbeda karena hadirnya covid-19 di Kota Bandung.

\section{METODE PENELITIAN}

Penelitian ini menggunakan metode kualitatif karena tujuannya cenderung untuk menjelaskan bagaimana interaksi dalam kegiatan ekonomi dan sosial terjadi antara mahasiswa dengan masyakat. Salah katu kata kunci dalam penelitian ini adalah efek demonstrasi yang diasumsikan terjadi terhadap masyarakat "pinggir kota". Hal ini tentu kurang bermakna bila didekati dengan penelitian kuantitatif yang lebih menekankan pada pembuktian hipotesis dengan menggambarkan fenomena melalui angka dan statistika

Penelitian ini menempatkan posisinya untuk mendapatkan gambaran yang lebih komprehensif dengan memasuki ruang interaksi sehingga tergambarkan tempat, pelaku dan aktivitasnya (place, actor and activities). Tempat penelitian dilakukan di Kota Bandung tepatnya di daerah Taman Sari Bawah, aktor dalam penelitian ini adalah lima orang mahasiswa pulang kampung dari berbagai daerah, seperti Cirebon, Ciamis, Bogor, Kuningan, dan Cianjur, serta lima orang masyarakat penghuni tetap di daerah Taman Sari Bawah Kota Bandung. Sedangkan untuk aktifitas penelitian ini adalah kegiatan konsumsi yang dilakukan mahasiswa pulang kampung dan masyarakat secara online seperti menggunakan wawancara via video call yang dilaksanakan di rumah mereka masing-masing, sehingga peneliti dapat melihat kondisi rumah mereka yang kemungkinan akan mencerminkan perilaku konsumsi, karena konsumsi secara umum dapat dipengaruhi oleh pendapatan, lingkungan dan kebutuhan.

\section{HASIL DAN PEMBAHASAN}

1. Pola Konsumsi Mahasiswa

a. Pola Konsumsi Mahasiswa Sebelum Covid-19

Berdasarkan wawancara online dengan beberapa mahasiswa pulang kampung di Kawasan Taman Sari Bawah Kota Bandung dapat diartikan bahwa konsumsi rutin mahasiswa yang tinggal di pondokan sebelum covid-19 seperti biaya makan, listrik, trasportasi, air, pulsa serta kebutuhan rumah tangga lainnya seperti sabun, pasta gigi, sampo, bedak dan lain sebagainya. Sedangkan konsumsi yang tidak rutin adalah setiap tambahan pengeluaran yang tidak terduga. Konsumsi mahasiswa diluar dari konsumsi makanan biasanya hanya berpusat pada bidang perkuliahan, seperti 
photo copy, biaya internet, mencetak tugas, dan lain sebagainya. Jika dikelompokkan maka konsumsi non makanan mahasiswa bergerak dalam empat hal yaitu transportasi, komunikasi meliputi biaya pulsa, internet, dan lain sebagainya; hiburan meliputi pembelanjaan untuk membeli pakaian, handphone, laptop, aksesoris dan lain sebagainya.

Dalam setiap bulan pengeluaran mahasiswa termasuk konsumtif untuk pengeluaran makanan, aktivitas penunjang kuliah, fashion, hiburan dan laundry sedangkan pengeluaran tidak konsumtifnya dalam hal komunikasi dan transportasi dengan pola konsumsi masing-masing berkisar 30\%, 15\%, 5\%, 5\%, 15\%, 10\% dan 20\%. Seperti terlihat dalam gambar di bawah ini

\section{Gambar 1. Diagram Pola Konsumsi Mahasiswa Sebelum Covid-19}

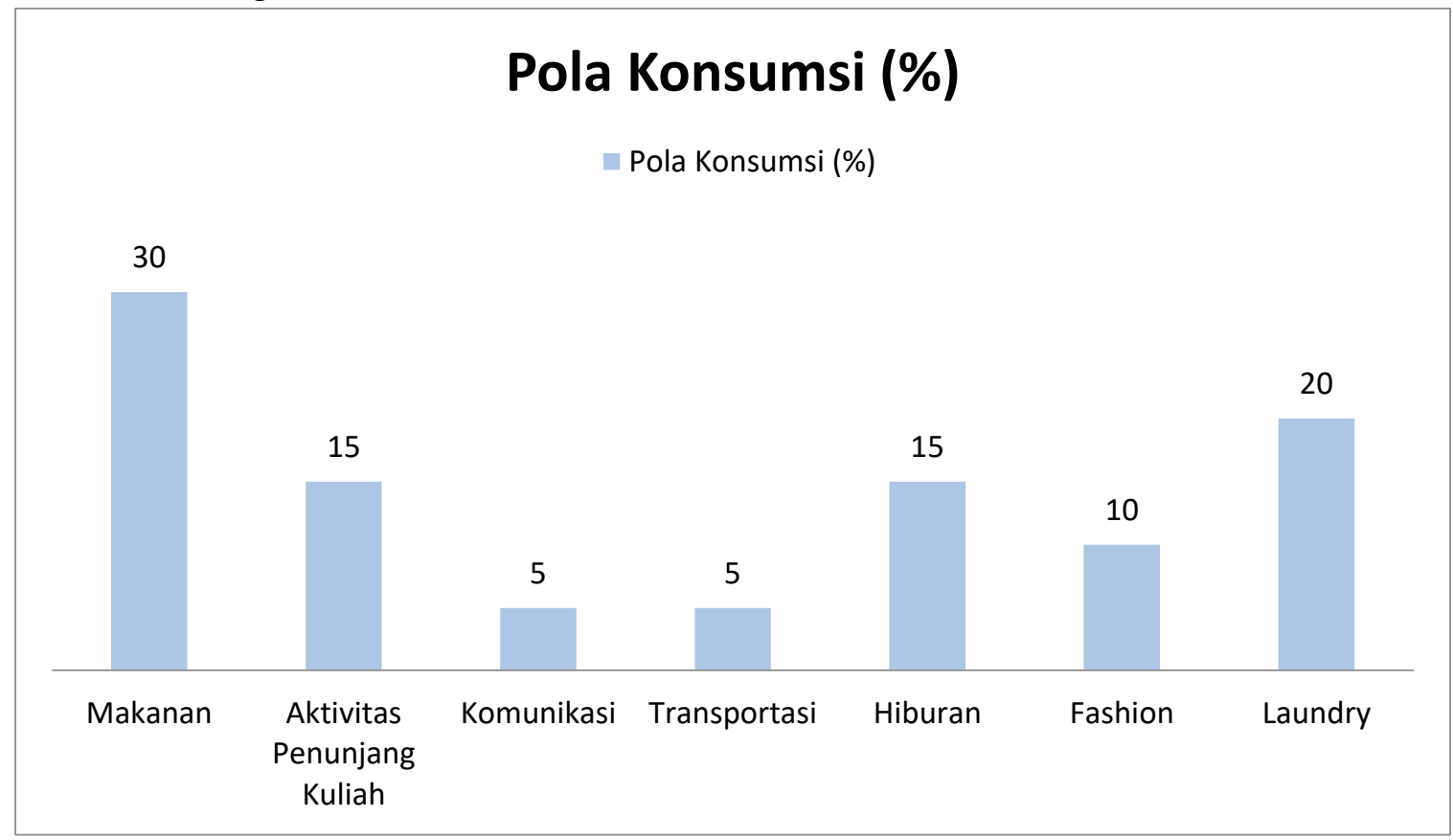

Berdasarkan diagram diatas dapat dijelaskan pengeluaran utama mahasiswa terdiri dari keperluan makanan, aktivitas penunjang kuliah, komunikasi, transportasi, hiburan, fashion dan laundry (masing-masing berkisar 30\%, 15\%, 5\%, 5\%, 15\%, 10\% dan 20\%). Hal ini sejalan dengan wawancara online yang dilakukan kepada mahasiswa asal Ciamis yaitu : "S". "S" menjelaskan bahwa "kalo saya Teh selama di kosan lebih banyak beli makanan di warteg pinggiran kosan sama laundry soalnya padet Teh gak ada waktu buat nyuci baju,. Jadi, baju saya ke laundrykan aja Teh. Kalo masalah penggunaan kouta, dikosan aku udah masang wifi setiap bulannya kita bayar 50 ribu ke Ibu kosnya patungan sama anak-anak kosan Teh. Udh kaya kebutuhan aja gitu internet tuh.

Dari pengamatan dan wawancara online yang dilakukan kepada informan mahasiswa asal Ciamis yang bernama " $S$ ", maka diperoleh beberapa butir resume yaitu :

1) Jenis pengeluaran utama mahasiswa adalah : (i) makanan; (ii) aktivitas penunjang kuliah; (iii) komunikasi; (iv) transportasi; (v) fashion; (vi) hiburan; (vii) laundry 
2) Berdasarkan jumlah penerimaan orang tua setiap bulannya mahasiswa termasuk konsumtif untuk pengeluaran makanan, aktivitas penunjang kuliah, fashion, hiburan dan laundry serta tidak konsumtif untuk pengeluaran komunikasi dan transportasi.

3) Pengeluaran utama mahasiswa rata-rata setiap bulannya sebesar Rp.500.000

\section{b. Pola Konsumsi Mahasiswa Setelah Covid-19}

Berdasarkan wawancara online dengan beberapa mahasiswa di Kawasan Taman Sari Bawah Kota Bandung dapat diartikan bahwa konsumsi rutin mahasiswa setelah covid-19 seperti pulsa internet, karena kegiatan mereka dihabiskan di rumah sehingga konsumsi rutin hanya berpusat pada bidang perkuliahan, seperti photo copy, biaya internet, mencetak tugas, dan lain sebagainya. Jika dikelompokkan maka konsumsi non makanan mahasiswa bergerak dalam empat hal yaitu transportasi, komunikasi meliputi biaya pulsa, internet, dan lain sebagainya; hiburan meliputi pembelanjaan untuk, handphone, laptop, dan lain sebagainya. Dalam setiap bulan pengeluaran mahasiswa termasuk konsumtif untuk aktivitas penunjang kuliah. Seperti terlihat dalam gambar di bawah ini

Gambar 2. Diagram Pola Konsumsi Mahasiswa Setelah Covid-19

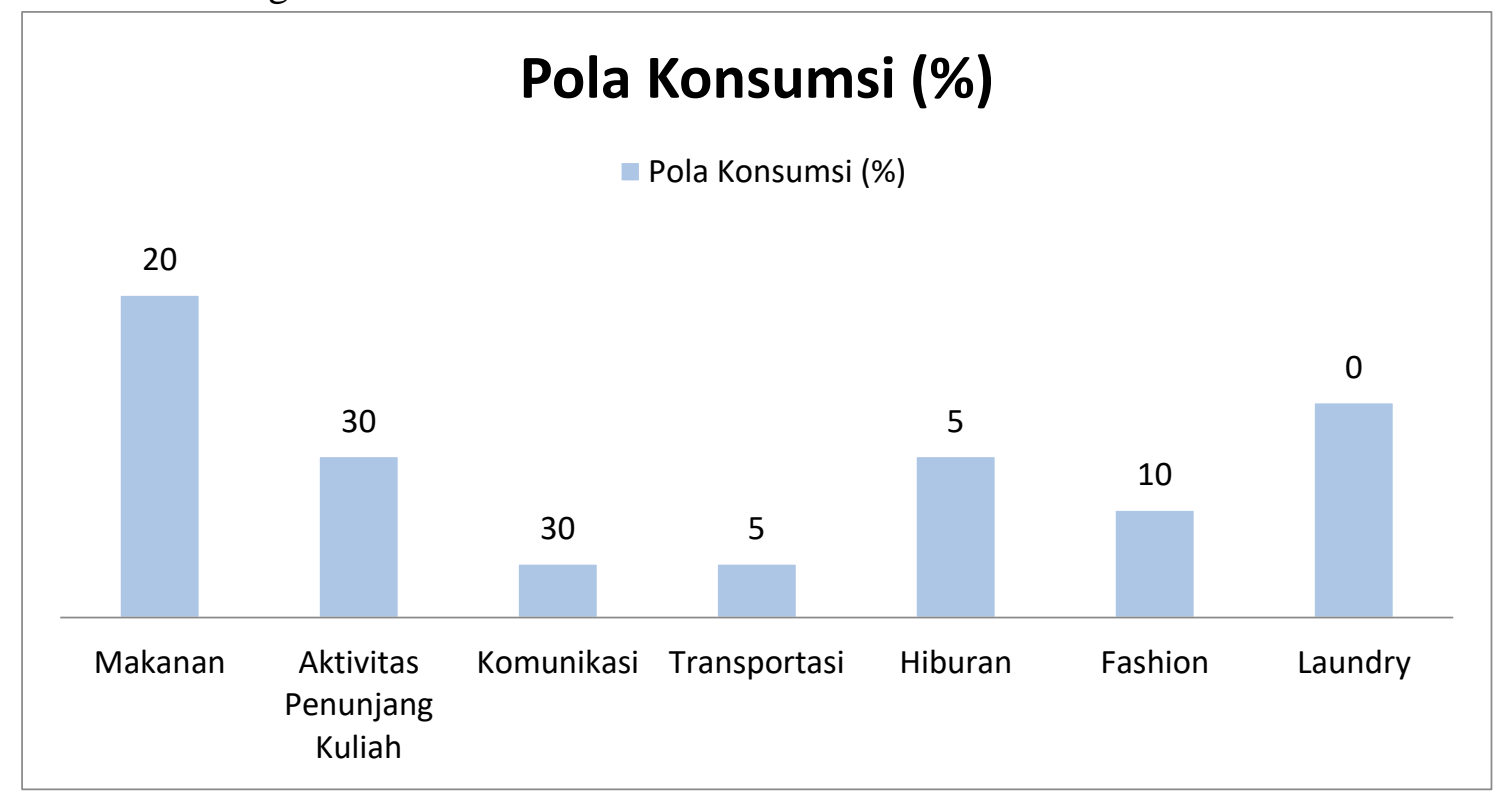

Berdasarkan diagram diatas dapat dijelaskan pengeluaran utama mahasiswa terdiri dari makanan, aktivitas penunjang kuliah, komunikasi, transportasi, hiburan, dan fashion (masing-masing berkisar 20\%, 30\%, 30\%, 5\%, 5\%, dan 10\%). Salah satu contoh aktivitas penunjang kuliah dan komunikasi adalah penggunaan pulsa. Pada saat pandemi covid-19, penggunaan pulsa bukan sekedar keinginan sudah menjadi kebutuhan mahasiswa, sehingga pola konsumsi mahasiswa pulang kampung memiliki keinginan yang besar untuk membeli makanan dan baju secara online sehingga porsi anggaran yang digunakan mahasiswa pulang kampung dimulai dari makanan, fashion, hiburan dan transportasi yang terdiri dari $(20 \%, 10 \%, 5 \%$ dan $5 \%)$.

Hal ini sejalan dengan wawancara online yang dengan salah satu mahasiswa asal Cirebon yaitu : "A”. "A” menjelaskan bahwa "kalo aku Teh, selama pandemi covid-19 
ini di rumahku di Cirebon lebih sering beli kouta terus, udah kaya kebutuhan pokok jeh kalo keinginan dirumah itu pengen makan mulu, padahal keluar susah gak boleh yaa aku mesen makanan via online terus kalo ada waktu kosong gak kuliah daring aku liatliat e-commerce suka jadi pingin beli baju. Yaaah..kira-kira setiap bulan 300 ribu habis buat makanan, baju belanja online semua."

Dari pengamatan dan wawancara online yang dilakukan kepada informan mahasiswa pulang kampung " $A$ " diperoleh beberapa butir resume yaitu :

1) Jenis pengeluaran utama mahasiswa adalah : (i) makananan, (ii) fashion; (iii) transportasi; dan (iv) hiburan

2) Berdasarkan jumlah penerimaan orang tua setiap bulannya mahasiswa termasuk konsumtif untuk makanan dan fashion dan tidak konsumtif untuk pengeluaran hiburan dan laundry.

3) Pengeluaran utama mahasiswa rata-rata setiap bulannya sebesar Rp.300.000

2. Pola Konsumsi Masyarakat

a. Pola Konsumi Masyarakat Sebelum Covid-19

Berdasarkan wawancara online dengan beberapa masyarakat di Kawasan Taman Sari Bawah Kota Bandung dapat diartikan bahwa pola konsumsi masyarakat sebelum covid-19 di daerah Taman Sari Bawah termasuk konsumtif untuk masalah fashion dan hiburan karena sering berinteraksi dengan mahasiswa sehingga sesuai dengan asumsi dari teori Duesenberry (1949) menyatakan bahwa konsumsi seseorang atau kelompok masyarakat dalam waktu tertentu merupakan fungsi dari konsumsi orang lain atau kelompok lainnya atau yang lebih dikenal efek demonstrasi. Efek demonstrasi merupakan efek pada perilaku individu yang disebabkan oleh pengamatan tindakan orang lain (dalam penelitian ini diasumsikan didapatkan dari interaksi antar keduanya). sedangkan tidak konsumtif untuk masalah transportasi, pendidikan dan makanan. Seperti terlihat dalam gambar di bawah ini

Gambar 3. Diagram Pola Konsumsi Masyarakat Sebelum Covid-19

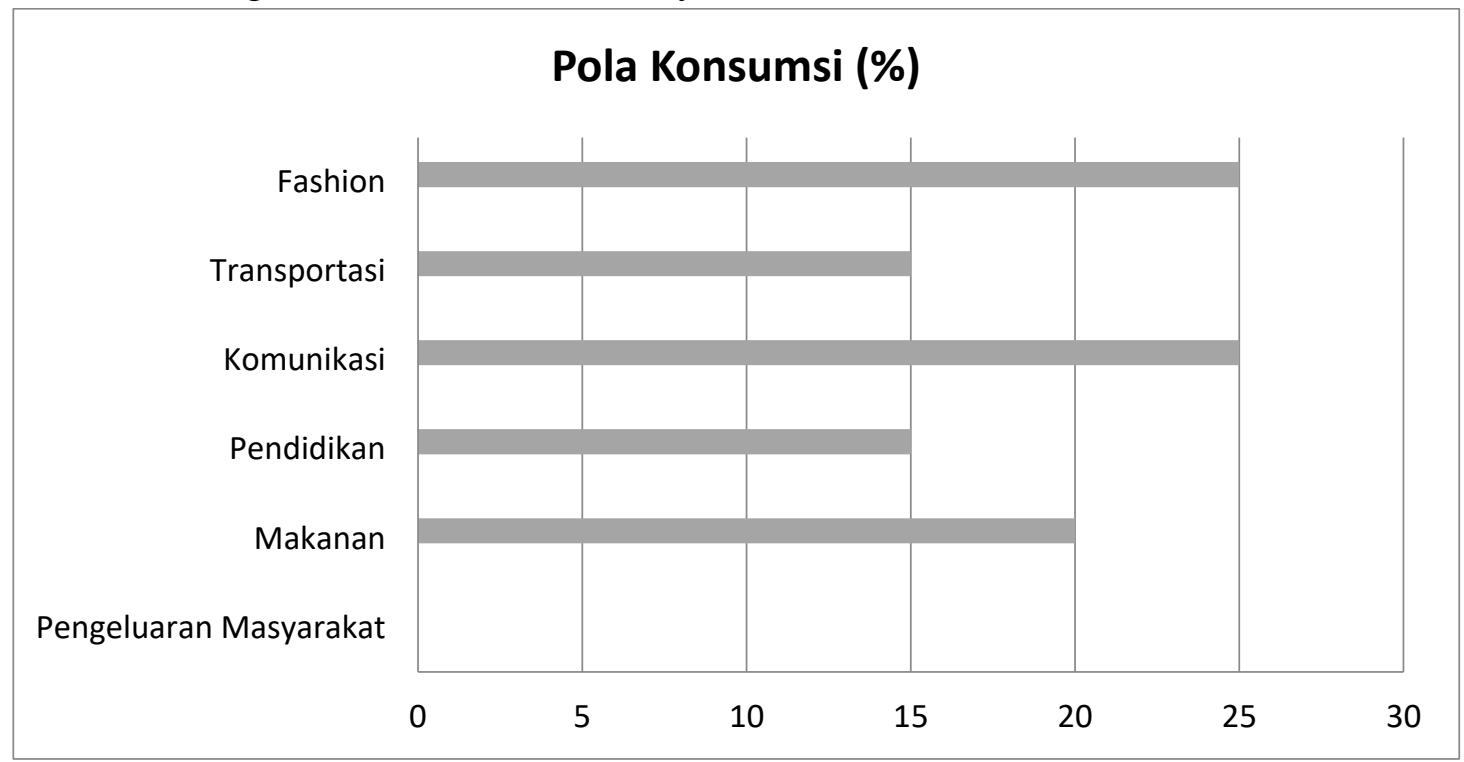


Hal ini sejalan dengan wawancara online yang dilaksanakan dengan informan " $\mathrm{B}$ " selaku masyarakat penghuni tetap yang menjelaskan bahwa: "Neng, Kalo Bapa mah kalo lihat mahasiswa gitu mondar-mandir depan rumah th suka diperhatiin sama Bapa mah gaya-gayanya suka keren gitu baju-baju jadi suka pengen beli gitu baju kaya kemeja yang mereka pakai teh, kadang-kadang gak kerasa beliin anak yang merk distro di daerah Trunojoyo kan lumayan harganya yang neng bisa sampe $500 \mathrm{rb} / \mathrm{bulan}$ buat beli baju juga. Hehehe."

Berdasarkan pengamatan dan wawancara secara online yang dilakukan kepada informan masyarakat "B" diperoleh beberapa butir resume yaitu:

1. Jenis pengeluaran utama masyarakat di daerah Taman Sari Bawah adalah (i) makanan; (ii) komunikasi; (iii) transportasi; (iv) fashion; (v) pendidikan (masingmasing berkisar 20\%, 15\%, 25\%, 15\% dan 25\%)

2. Berdasarkan jumlah pendapatan yang dimiliki setiap bulannya masyarakat di daerah Taman Sari Bawah termasuk konsumtif untuk jenis pengeluaran fashion dan komunikasi serta tidak konsumtif untuk jenis pengeluaran makanan, transportasi dan pendidikan.

3. Sebagian gaya hidup dan konsumsi masyarakat mengikuti gaya hidup dan konsumsi mahasiswa seperti makanan dan fashion. Sesuai dengan hasil penelitian Duesenberry (1949) bahwa konsumsi seseorang dipengaruhi lingkungan sekitarnya (efek demonstrasi).

4. Dengan adanya interaksi yang dilakukan masyarakat dengan mahasiswa mengakibatkan pola konsumsi masyarakat berubah mengikuti mahasiswa

b. Pola Konsumi Masyarakat Setelah Covid-19

Berdasarkan wawancara online dengan beberapa masyarakat di Kawasan Taman Sari Bawah Kota Bandung dapat diartikan bahwa pola konsumsi masyarakat setelah covid-19 di daerah Taman Sari Bawah termasuk konsumtif untuk masalah kesehatan dan pendidikan karena wabah ini mengharuskan masyarakat hidup sehat seperti sering cuci tangan dan memakai masker sehingga 1 Kepala Keluarga bisa menghabiskan Rp. 200.000/bulan untuk membeli masker kain, sabun cuci tangan, dan handsanitizer sedangkan untuk pendidikan, wabah ini menyebabkan anak-anak belajar di rumah sehingga pembelian pulsa internet bisa mencapai Rp.100.000/bulan

Pengeluaran kesehatan dan pendidikan yang meningkat setiap bulannya karena beberapa masyarakat sering berinteraksi dengan masyarakat atau tetangga mereka yang peduli terhadap kesehatan dan pendidikan sehingga sesuai dengan asumsi dari teori Duesenberry (1949) menyatakan bahwa konsumsi seseorang atau kelompok masyarakat dalam waktu tertentu merupakan fungsi dari konsumsi orang lain atau kelompok lainnya atau yang lebih dikenal efek demonstrasi. Efek demonstrasi merupakan efek pada perilaku individu yang disebabkan oleh pengamatan tindakan orang lain (dalam penelitian ini diasumsikan didapatkan dari interaksi antar keduanya). sedangkan tidak konsumtif untuk masalah fashion karena setelah covid-19 masyarakat kurang berinteraksi langsung dengan mahasiswa dikarenakan mahasiswa yang kebanyakan pulang ke daerah mereka masing-masing. Seperti terlihat dalam gambar di bawah ini 


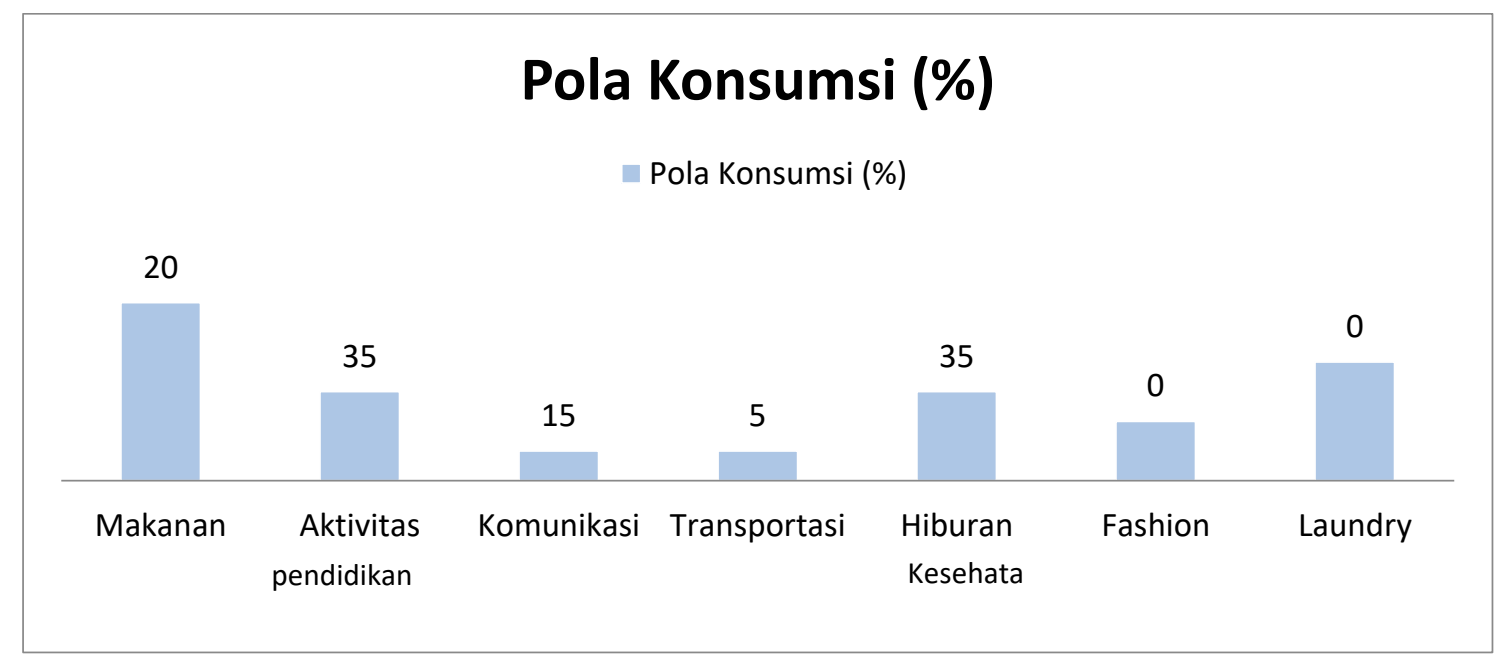

Hal ini sejalan dengan wawancara online yang dilakukan kepada informan masyarakat yang bernama " $C$ ". "C" menjelaskan bahwa : "Ada corona gini th jadi parno neng, ibu mah jadi beli masker kain sekali beli 3, belum lagi hand sanitizer beli 3 kan anak ibu ada 3, semua pada kerja di pabrik, jadi gak pada libur gak ada istilah bekerja dari rumah buat keluarga ibu belum lagi bapa jualan ketemua orang banyak jadi parno ngebeliin masker, tapi sekarang mh lagi sepi neng, jadi bapa di rumah weh.”

Berdasarkan pengamatan dan wawancara yang dilakukan kepada informan masyarakat yang bernama " $C$ ", diperoleh beberapa butir resume yaitu:

1) Jenis pengeluaran utama masyarakat di daerah Taman Sari Bawah adalah (i) makanan; (ii) pendidikan; (iii) komunikasi; (iv) transportasi; (v) kesehatan (masingmasing berkisar $20 \%, 35 \%, 15 \%, 5 \%$ dan $35 \%$ )

2) Berdasarkan jumlah pendapatan yang dimiliki setiap bulannya masyarakat di daerah Taman Sari Bawah termasuk konsumtif untuk jenis pengeluaran i serta kesehatan dan pendidikan sedangkan tidak konsumtif untuk jenis pengeluaran fashion dan laundry.

3) Sebagian gaya hidup dan konsumsi masyarakat mengikuti gaya hidup dan konsumsi masyarakat sekitarnya seperti kesehatan dan pendidikan. Sesuai dengan hasil penelitian Duesenberry (1949) bahwa konsumsi seseorang dipengaruhi lingkungan sekitarnya (efek demonstrasi).

4) Dengan adanya interaksi yang dilakukan masyarakat dengan msyarakat sekitarnya mengakibatkan pola konsumsi masyarakat berubah mengikuti lingkungan sekitarnya.

\section{KESIMPULAN}

Covid-19 berkisar antara Rp.500.000 hingga Rp.1.000.000 per bulan. Berdasarkan besarannya pengeluaran itu digunakan untuk keperluan makanan, aktivitas penunjang kuliah, komunikasi, transportasi, hiburan, fashion dan laundry (masingmasing berkisar 30\%, 15\%, 5\%, 5\%, 15\%, 10\% dan 20\%). Sedangkan pengeluaran mahasiswa setelah covid-19 berkisar antara RP. 300.000 hingga Rp. 500.000, pengeluaran utama mahasiswa terdiri dari . Dilihat dari tingkat dan corak pengeluaran ini maka dapat dikatakan bahwa mahasiswa termasuk konsumtif pada saat sebelum 
covid-19 dibandingkan setelah adanya covid-19 makanan, fashion, hiburan dan transportasi yang terdiri dari $(20 \%, 10 \%, 5 \%$ dan 5\%). Karena setelah covid-19, aktivitas untuk mengerjakan tugas-tugas kuliah sudah menjadi kebutuhan bukan keinginan, sehingga mahasisa pulang kampung lebih banyak menghabiskan anggaran untuk makanan dan fashion yang mereka beli secara online.

Gaya hidup dan konsumsi masyarakat mengikuti gaya hidup dan konsumsi masyarakat sekitarnya setelah adanya covid-19 dapat dilihat dari pengeluaran masyarakat yang tinggal di daerah Taman Sari Bawah berkisar antara Rp.3.000.000 hingga Rp.5.000.000 per keluarga (dengan jumlah keluarga 3-4 orang) per bulan. Berdasarkan besarannya pengeluaran itu digunakan untuk pengeluaran utama masyarakat di daerah Taman Sari Bawah adalah (i) makanan; (ii) pendidikan; (iii) komunikasi; (iv) transportasi; (v) kesehatan (masing-masing berkisar 20\%, 35\%, 15\%, 5\% dan 35\%). Dilihat dari tingkat dan corak pengeluaran ini maka dapat dikatakan bahwa masyarakat di daerah Taman Sari Bawah termasuk konsumtif dalam hal kesehatan dan pendidikan. Ada kemungkinan pola konsumsi masyarakat di daerah Taman Sari Bawah juga dipengaruhi oleh interaksi mereka dengan masyarakat sekitarnya, selain dari faktor-faktor lainnya.

\section{DAFTAR PUSTAKA}

Duesenberry, J.S. (1949). Income, Saving and the Theory of Consumer Behavior. Harvard University Press, Cambridge.

Indrianawati, E., dan Soesatyo, Y. (2017). Pengaruh tingkat pendapatan dan pengetahuan ekonomi terhadap tingkat konsumsi mahasiswa program Pascasarjana Universitas Negeri Surabaya. Jurnal Ekonomi Pendidikan dan Kewirausahaan, 3(2), 214-226.

Larasati, RA. (2014). Interaksi dan Pola Konsumsi Mahasiswa dan Masyarakat. Skripsi. Fakultas Ekonomi Universitas Pasundan Bandung

Larasati, RA. (2019). Interaksi dan Pola Konsumsi. Bandung : STAI Yamisa Soreang.

Mufidah, N. L. (2012). Pola konsumsi masyarakat perkotaan: studi deskriptif pemanfaatan foodcourt oleh keluarga. Jurnal Biokultur, 2, 157-178.

Pakpahan, A. K. (2020). Covid-19 dan Implikasi Bagi Usaha Mikro, Kecil, dan Menengah. Jurnal Ilmiah Hubungan Internasional, 59-64.

Parsaulian, B., Aimon, H., \& Anis, A. (2013). Analisis konsumsi masyarakat di Indonesia. Jurnal Kajian Ekonomi, 1(2).

Pemkot Bandung (2020). Data Jumlah Kasus Covid-19. Dalam covid19.bandung.go.id diakses pada tanggal 17 Mei 2020 Pukul 15.30 WIB.

Saragih, Bernatal, and Frederic Morado Saragih (2020). Hubungan Berbagai Faktor Dengan Kebiasaan Makan Pada Masa Pandemi Covid 19. Dalam https://www.researchgate.net/ yang diakses pada tanggal 14 Juni 2020 Pukul 19.31 WIB 